\title{
The effect of slaughter age and aging period on water-holding capacity and tenderness of mutton
}

\author{
Ana Kaić ${ }^{1 *}$, Ivan Širić1 , Silvester $\check{Z ̆ g u r}^{2}$, Gordan Šubara ${ }^{3}$, and Boro Mioč \\ ${ }^{1}$ Department of Animal Science and Technology, University of Zagreb Faculty of Agriculture, Zagreb, Croatia \\ ${ }^{2}$ Department of Animal Science, University of Ljubljana, Biotechnical Faculty, Domžale, Slovenia \\ ${ }^{3}$ Agency for Rural Development of Istria Ltd. Pazin (AZZRI), Pazin, Croatia
}

KAIĆ, A., I. ŠIRIĆ, S. ŽGUR, G. ŠUBARA, B. MIOČ: The effect of slaughter age and aging period on waterholding capacity and tenderness of mutton. Vet. arhiv 90, 611-616, 2020.

\section{ABSTRACT}

Mutton samples (m. longissimus thoracis et lumborum; LL) originating from 30 Istrian ewes were used to determine EZ drip loss (DL), thaw loss (TL), cooking loss (CL), and Warner-Bratzler shear force (WBSF) in relation to age at slaughter and different post mortem aging periods (1, 7, and 14 days). DL was measured according to the EZ method after storage periods of 24 and $48 \mathrm{~h}$. Determination of TL, CL, and WBSF was performed for samples aged prior to freezing for 1,7 , and 14 days. A significantly lower TL $(\mathrm{P}<0.05)$ was observed in the mutton samples that aged for 1 day $(7.76 \%)$ prior to freezing compared to the mutton samples that aged for 7 days $(9.91 \%)$ and 14 days $(9.32 \%)$ prior to freezing. The WBSF revealed significant differences between the aging periods $(\mathrm{P}<0.05)$, indicating that mutton aged $7(33.92 \mathrm{~N})$ and $14(28.23 \mathrm{~N})$ days showed greater tenderness than mutton with a shorter aging period $(43.89 \mathrm{~N})$. Considering that there was no significant difference between mutton aged for 7 and 14 days in water-holding capacity and shear force, there is no reasonable reason for aging mutton longer than 7 days. Therefore, further research into shorter aging periods, the sensory quality of mutton, and its acceptability by consumers is needed.

Key words: sheep; shear force; drip loss; thaw loss; cooking loss

\section{Introduction}

The Istrian sheep is an indigenous Croatian breed from the Istrian peninsula, predominately used for dairy production, accompanied by lamb production. Its meat is predominately used for production of specific local meat products, such as sausages or salami. In Croatia, as in many other countries, mutton is not often purchased as fresh meat. Fresh mutton is often repulsive to the consumers due to the general opinion that is tough, with excessive fat content, and its specific odor and aroma (CERNY, 2012; CONSTANTINO et al., 2014).
In general, it is known that water-holding capacity (WHC) and tenderness are important meat quality attributes associated with consumer acceptance and processing technology. Poor WHC results in high drip from meat and meat products, which can represent a significant loss of weight from carcasses and cuts, and may affect the yield and quality of processed meats (WARNER, 2017). Tenderness is the most important attribute that affects the consumer acceptability and eating pleasure of meat products (JIMÉNEZ-COLMENERO et al., 2016).

\footnotetext{
*Corresponding author:

Ana Kaić, PhD, Department of Animal Science and Technology, Faculty of Agriculture, Svetošimunska c. 25, Zagreb, Croatia, Phone: +385 1239 3650; E-mail: akaic@agr.hr
} 
Apart from the attributes mentioned, it has been shown that the quality of meat for consumption is inseparably linked to other factors, such as age at slaughter and the aging period. Studies on the meat quality of lamb and sheep have reported a decrease in WHC and an increase in shear force with the increasing the age of the animals (ALEXANDRIDIS et al., 2016; RANT et al., 2019). Furthermore, it has been shown that the process of aging is associated with favourable changes in meat tenderness and its WHC (FAROUK et al., 2012; RANT et al., 2019).

However, the literature data related to mutton show that the appropriate aging period for mutton has not yet been determined, and information related to its main quality attributes is quite limited. This information on mutton is required for producers, processing technology and also for consumers in their decision at the point of purchase of fresh or processed meat. Thus, the aim of this study was to determine the WHC and tenderness of mutton in relation to the age at slaughter and different post mortem aging periods.

\section{Materials and methods}

Animals, slaughtering and sampling. Altogether, 30 Istrian ewes were involved in the study. The ewes were selected as animals reared in a dairy oriented, semi-intensive breeding environment, and they were culled from the flocks when their milk production fell below the acceptable level. The average age of the animals was 90 months, and ranged from 36 to 120 months. The animals were slaughtered and processed according to the procedures previously described by KAIĆ et al. (2016). The carcasses were chilled at $4{ }^{\circ} \mathrm{C}$ for $24 \mathrm{~h}$ in a cold chamber. Muscle samples for analysis were taken from the loin (M. longissimus thoracis et lumborum - LL) of each left carcass side at $24 \mathrm{~h}$ post mortem. The LL was removed from cranial edge to the $12 / 13^{\text {th }}$ rib. The samples were transported to the laboratory for further analysis.

Analytical methods. Drip loss (DL) was measured according to the EZ method described by RASMUSSEN and ANDERSSON (1996). The samples for the EZ method were removed from the cranial part of the LL muscle. Two samples were taken from each slice of $25 \mathrm{~mm}$ thickness using a circular knife (Ø $25 \mathrm{~mm}$ ). After that, the samples were placed in specialized EZ drip loss containers. Muscle samples and containers were weighed before and after the storage periods of $24 \mathrm{~h}$ (DL_24) and $48 \mathrm{~h}$ (DL_48). Before each weighing, there was no need to dab the muscle core samples. The EZ drip loss was expressed as a percentage relative to the initial weight.

Determination of Warner-Bratzler shear force (WBSF) was performed on three samples subsequently removed from the LL muscle, following the slice taken for EZ drip loss. The samples for WBSF were packed under vacuum and stored under refrigerated conditions (at $2{ }^{\circ} \mathrm{C}$ ). One slice of the LL sample was aged for a period of $24 \mathrm{~h}$ and then frozen at $-20{ }^{\circ} \mathrm{C}(1$ day aged samples; first aging, $n=30$ ), whereas the others were stored under refrigerated conditions for another 7 days (second aging, $\mathrm{n}=30$ ) and 14 days (third aging, $\mathrm{n}=30$ ). At the end of the second and third aging periods, the samples of LL were immediately frozen at -20 ${ }^{\circ} \mathrm{C}$. After the 30 day storage period, the samples of LL $(n=90)$ were used for evaluation of thaw loss (TL), cooking loss (CL) and WBSF. Thawing of the frozen LL samples was performed under controlled refrigerated conditions at $4{ }^{\circ} \mathrm{C}$ for a period of 24 $h$. Thawed meat samples were removed from the vacuum bags, dried with paper towels and weighed. TL was estimated as the percentage of weight loss of the thawed sample in relation to the initial sample weight.

In order to measure CL, thawed meat samples were weighed, placed in polyethylene bags and cooked in a boiling water bath. When the endpoint core temperature of $75^{\circ} \mathrm{C}$ was attained, the samples were removed from the water bath, cooled in an ice slurry and held under chilled conditions $\left(4{ }^{\circ} \mathrm{C}\right)$ until equilibrated. After that, the samples were taken from the polyethylene bags, dried with paper towels and weighed. CL was estimated as the percentage of weight loss of the cooked sample in relation to the initial sample weight.

The WBSF was determined in relation to the cooked samples as mentioned above, using an Instron Universal Testing machine (Model 3345, 
Instron, Canton, MA, USA) equipped with a WBSF device. Cooked samples were stored at $4{ }^{\circ} \mathrm{C}$ for $24 \mathrm{~h}$ in a refrigerator. Each sample was cut into eight square cores $(1 \times 1 \times 2.5 \mathrm{~cm})$ parallel to the muscle fibers, and sheared once, perpendicular to the long axis of the fibers at a cross-head speed of $250 \mathrm{~mm} /$ minute using a 500 Newton load cell. The mean value of the eight replicates was taken as the maximum shear force value, and was recorded for further statistical analysis.

Statistical analysis. The WHC and tenderness of the mutton were analysed using the SAS/STAT software package version 9.4 (SAS Inst. Inc., 2004). Descriptive statistics of the investigated traits were analysed using the MEANS procedure, whereas the effect of slaughter age and aging period were analysed using MIXED procedures. The best fit model for TL, CL and WBSF included the overall mean $(\mu)$, the linear regression coefficient $(\beta)$ of age in months (xij), aging period ( $\mathrm{i}=1,7$, and 14 days) as fixed effects, and the random residual (eij). For the evaluation of EZ_24 and EZ_48, the aging period as a fixed effect was excluded from the aforementioned model. Post hoc comparison between the least square means was performed using a Bonferroni multiple test correction. Differences were considered if $\mathrm{P}<0.05$.

\section{Results}

Descriptive statistics for the meat quality attributes of mutton are presented in the Table 1. The results showed that the mean value for DL_24 was lower than for DL_48. The effect of slaughter age on DL is presented in Table 2. The results indicated that there was no significant influence of age on DL measured at $24 \mathrm{~h}(\mathrm{P}=0.824 ; \beta=0.001$ per month $)$ and $48 \mathrm{~h}(\mathrm{P}=0.966 ; \beta=0.002$ per month $)$.

The mean TL values for mutton samples for the three different aging periods is presented in Table 1. Among our samples, it is of interest to emphasize that a significantly lower TL $(\mathrm{P}<0.05$; Table 2$)$ was observed in the mutton that aged for 1 day prior to freezing compared to the mutton that aged for 7 days and 14 days prior to freezing. The TL parameter did not differ significantly with increasing age $(\mathrm{P}=$ $0.979 ; \beta=-0.002$ per month).
Table 1. Means with standard deviation (SD), coefficients of variation (CV), minimum (Min), and maximum (Max) for meat quality attributes of mutton $(\mathrm{n}=30)$

\begin{tabular}{|l|c|c|c|c|c|c|}
\hline Attribute & & Mean & SD & CV & Min & Max \\
\hline DL_24, \% & & 0.57 & 0.486 & 84.82 & 0.01 & 2.06 \\
\hline DL_48, \% & & 0.89 & 0.580 & 64.87 & 0.24 & 2.83 \\
\hline & $\begin{array}{c}\text { Aging } \\
\text { (days) }\end{array}$ & & & & & \\
\hline TL, \% & 1 & 7.79 & 1.38 & 17.72 & 5.33 & 10.51 \\
\hline TL, \% & 7 & 9.99 & 1.75 & 17.55 & 6.56 & 15.24 \\
\hline TL, \% & 14 & 9.81 & 2.96 & 30.20 & 6.41 & 18.88 \\
\hline CL, \% & 1 & 25.07 & 3.42 & 13.66 & 17.22 & 33.15 \\
\hline CL, \% & 7 & 26.07 & 3.60 & 13.84 & 17.52 & 32.57 \\
\hline CL, \% & 14 & 25.60 & 4.36 & 17.03 & 19.82 & 43.64 \\
\hline WBSF, N & 1 & 44.50 & 15.74 & 35.38 & 25.87 & 83.47 \\
\hline WBSF, N & 7 & 34.46 & 14.73 & 37.35 & 22.10 & 72.98 \\
\hline WBSF, N & 14 & 29.83 & 10.64 & 35.69 & 17.67 & 60.46 \\
\hline
\end{tabular}

DL_24 = EZ drip loss after $24 \mathrm{~h}$ storage; DL $48=\mathrm{EZ}$ drip loss after $48 \mathrm{~h}$ storage; $\mathrm{TL}=$ thaw loss, $\mathrm{CL}=$ cooking loss; WBSF $=$ Warner-Bratzler shear force.

The mean values for CL obtained during the different aging periods are presented in Table 1 . The results showed lower but insignificant CL values for the mutton that aged 1 day $(\mathrm{P}>0.05$; Table 2$)$ compared to the mutton with a longer aging period (7 vs. 14 days). Furthermore, it was found that there was no significant difference in CL between mutton aged for 7 and 14 days $(\mathrm{P}>0.05)$. The increase in slaughter age was not followed by an increase in $\mathrm{CL}$ values $(\mathrm{P}=0.481 ; \beta=0.012$ per month).

Analysing the WBSF, it was found that the mean value for mutton aged for 1 and 7 days was greater than the shear forces found for mutton aged for 14 days (Table 1). The WBSF revealed significant differences between the aging periods $(\mathrm{P}<0.05)$, indicating that mutton that aged for 7 and 14 days showed greater tenderness than mutton with a shorter aging period (Table 2). The WBSF did not differ significantly with increasing age at slaughter $(\mathrm{P}=0.107 ; \beta=0.095$ per month). 
Table 2. Effect of aging period and age at slaughter on EZ drip loss (DL), thawing loss (TL), cooking loss (CL), and Warner-Bratzler shear force (WBSF) of mutton $(\mathrm{LSM} \pm \mathrm{SE})$

\begin{tabular}{|l|c|c|c|c|c|}
\hline \multirow{2}{*}{} & \multicolumn{3}{|c|}{ Aging } & Age & \multirow{2}{*}{ P-value } \\
\cline { 2 - 5 } & 1 day & 7 days & 14 days & $\beta \pm$ SE & 0.824 \\
\hline DL_24*, \% & - & - & - & $0.001 \pm 0.004$ & 0.966 \\
\hline DL_48*, \% & - & - & - & $0.002 \pm 0.004$ & 0.979 \\
\hline TL, \% & $7.76 \pm 0.343^{\mathrm{a}}$ & $9.91 \pm 0.343^{\mathrm{b}}$ & $9.32 \pm 0.3439^{\mathrm{b}}$ & $-0.002 \pm 0.008$ & 0.481 \\
\hline CL, \% & $24.80 \pm 0.731$ & $26.24 \pm 0.731$ & $25.75 \pm 0.7318$ & $0.012 \pm 0.017$ & 0.107 \\
\hline WBSF, N & $43.89 \pm 2.45^{\mathrm{a}}$ & $33.92 \pm 2.451^{\mathrm{b}}$ & $28.23 \pm 2.451^{\mathrm{b}}$ & $0.095 \pm 0.058$ & \\
\hline
\end{tabular}

* For abbreviations see Table $1 ; \beta$ = regression coefficient for age in months; LSM with different letters in the same row significantly differ (Bonfferoni post hoc test, $\mathrm{P}<0.05$ ).

\section{Discussion}

The present study showed that the difference in mean values for DL_24 and DL_48 was $0.32 \%$. This was somewhat expected, since is known that exudation in muscle is a complex and slow process. FILHO et al. (2017), and HOLMAN et al. (2020) also confirmed this tendency for DL to increase with storage period.

Each aging, freezing and/or thawing process by itself, in sequence or combination, may result in different meat quality characteristics (KIM and KIM, 2017). According to KIM and KIM (2017), aging meat prior to freezing could improve the WHC of frozen or thawed meat, particularly thaw loss. KIM et al. (2011) investigated three different combinations of aging $(0,20$, and 40 days) and freezing (90, 70, and 50 days) on beef muscle quality traits. They reported that the non-aged beef had a significantly higher TL than the aged beef. Furthermore, they noticed that there was no difference in the TL of the beef samples that aged longer (20 vs. 40 days). SCHULTE et al. (2019) investigated the influence of different aging $(1,8$, 14, 21 days) and freezing ( $0,15,22,38,25$ days) periods on pork loin quality attributes. They found that TL increased in pork loins that aged prior to freezing from 1 to 8 days and 8 to 14 days, but decreased from 14 to 21 days. According to previous reports summarized by HOLLOWAY and WU (2019), increased TL could be due to protein denaturation, proteolysis during aging, chilling rate, and protein oxidation.
Regarding CL, SANTOS et al. (2012) reported that non-aged mutton had significantly lower CL than aged mutton, whereas no differences were found between $\mathrm{CL}$ in mutton with a longer aging period ( 7 vs. 14 day). In addition, KIM et al. (2011) found that non-aged beef had lower but insignificant CL than beef aged prior to freezing for 20 and 40 days. They also confirmed an insignificant difference in CL between samples aged 20 and 40 days prior to freezing. BRESSAN et al. (2001) explained that the greater CL of aged meat may be partially explained by the reduced water-holding capacity of aged muscle fibres, due to the disintegration of the protein matrix found in meat depending on natural enzymatic activity, which is magnified by the aging process. However, SCHULTE et al. (2019) found the highest $\mathrm{CL}$ in pork loins with the shortest aging period prior to freezing ( 1 day vs. 8, 14, and 21 days). As shown in Table 2, an increase in slaughter age was not followed by an increase in CL values. This could be due to the low variation in fat content (data not shown), and therefore moisture content, which would explain the similarity in CL among the investigated animals.

BIANCHINI et al. (2007) reported that the average WBSF values of meat with acceptable softness range should be below $5 \mathrm{~kg} / \mathrm{cm}^{2}$. The results for WBSF indicate that regardless of the aging period, our mutton samples on average could be classified as tender. However, the variation in the mean values that ranged from $60.46 \mathrm{~N}$ to 83.47 $\mathrm{N}$ during different aging periods, do not allow us 
to generalize in this regard and must be taken into consideration. In agreement with our results for WBSF between the aging periods, ABDULLAH and QUDSIEH (2009) reported that the WBSF of longissimus muscles from Awassi ram lambs significantly decreased with the aging period, with results from $28.3 \mathrm{~N}$ ( $24 \mathrm{~h}$ ) to $20.7 \mathrm{~N}$ (7 days). FLOREK et al. (2018) also reported that the WBSF of the semimebranosus muscle from commercial lamb meat significantly decreased during aging periods of two days $(55.9 \mathrm{~N})$ and 7 days $(28.8 \mathrm{~N})$. RANT et al. (2019) also confirmed significantly lower WBSF values in longissimus muscles aged for 14 days $(43.67 \mathrm{~N})$ compared to fresh, non-aged longissimus muscles (59.43 N) from Polish merino lambs. According to KOOHMARAIE (1996), the greater tenderness of aged meat could be associated with processes in the myofibrillar structure (proteolysis of cytoskeletal proteins, degradation of $\mathrm{Z}$ disks and some regulatory proteins) that cause the weakening of myofibrils and muscle relaxation, contributing to the improvement of tenderness.

Although is known that with increased age/ weight at slaughter, the nature of collagen changes (increased level of cross-linking), and its solubility is reduced, leading to less tenderness (ALEXANDRIDIS et al., 2016), the WBSF did not differ significantly with increasing age at slaughter.

The effect of the age at slaughter on decreasing meat tenderness was confirmed by YOUNG et al. (1993) in Romney lambs. It should be taken into consideration that the lambs in their study were younger and with a wider range of age than in the present research. The results showed that mutton aged for 1 day had lower TL and was tougher compared to mutton that was aged for longer ( 7 vs. 14 days).There was no significant difference in water-holding capacity and shear force between mutton aged for 7 or 14 days. Therefore, from this point of view, there is no reasonable purpose in aging mutton for longer than 7 days. Considering the financial cost of aging and the final effect on the meat, a shorter aging period should be considered in further investigations. It is expected that age at slaughter will not notably affect the meat quality attributes that could be of interest to consumers. Considering the above, and the lack of information related to other eating qualities of mutton that are of interest for consumers (e.g. odor, aroma), it is important to consider further investigations.

\section{Conflicts of interest}

The authors declare no conflicts of interest.

\section{Acknowledgements}

This study was supported by the Agency for Rural Development of Istria Ltd. Pazin (AZZRI).

\section{References}

ABDULLAH, A. Y., R. I. QUDSIEH (2009): Effect of slaughter weight and aging time on the quality of meat from Awassi ram lambs. Meat Sci. 82, 309-316.

DOI: 10.1016/j.meatsci.2009.01.027

ALEXANDRIDIS, V., B. SKAPETAS, D. KANTAS, P. GOULAS, M. KALAITZIDOU (2016): Evaluation the impact of carcass weight, age at slaughter, and sex on the chemical composition of lamb meat: the case of the Boutsiko sheep breed. Iran. J. Appl. Anim. Sci. 6, 119-124.

BIANCHINI, W., A. A. SILVEIRA, A. M. JORGE, M. B. ARRIGONI, C. L. MARTINS, E. RODRIGUES, J. C. HADLICH, C. ANDRIGHETTO (2007): Effect of genetic group on carcass traits and fresh and aged beef tenderness from young cattle Rev. Bras. Zootec. 36, 2109-2117 (in Portuguese).

DOI: 10.1590/S1516-35982007000900022

BRESSAN, M.C., O.V. PRADO, J. R. O. PÉREZ, A. L. S. C. LEMOS, S. BONAGURIO (2001): Effect of the slaughter weight on the physical-chemical characteristic of Bergamácia and Santa Inês lamb meat. Food Sci. Technol. 21, 293-303 (in Portuguese).

\section{DOI: 10.1590/S0101-20612001000300008}

CERNY, C. (2012): Savory flavors. In: Handbook of meat, poultry and seafood quality. Part two: Flavor. (Nollet, L.M.L., Ed.), John Wiley \& Sons Ltd., Iowa, UK, p. 105.

CONSTANTINO, C., E. L. AZAMBUJA RIBEIRO, A. M. BRIDI, M. A. TARSITANO, F. A. BOSCARO DE CASTRO, F. FERNANDES JÚNIOR, I. J. MIZUBUTI, E. SALES PEREIRA (2014): Performance, carcass and meat quality of ewes supplemented with magnesium oxide. Rev. Bras. Zootec. 43, 27-35.

DOI: $10.1590 / \mathrm{S} 1516-35982014000100005$

FAROUK, M. M., N. M. MUSTAFA, G. WU, G. KRSINIC (2012): The "sponge effect" hypothesis: An alternative explanation of the improvement in the waterholding capacity of meat with aging. Meat Sci. 90, 670-677.

DOI: 10.1016/j.meatsci.2011.10.012

FILHO, R. D. A. T., H. P. CAZEDEY, P. R. FONTES, A. D. L. S. RAMOS, E. M. RAMOS (2017): Drip loss assessment by different analytical methods and their relationships with pork quality classification. J. Food Qual. 1-8.

DOI: $10.1155 / 2017 / 9170768$ 
FLOREK, M., P. DOMARADZKI, A. JUNKUSZEW, P. SKAŁECKI, Z. LITWINCZUK, T. M. GRUSZECKI, W. BOJAR (2018): Comparison of physicochemical properties of meat of lambs and calves for slaughter. J. Anim. Sci., Biol. Bioecon. 36, 31-44 (in Polish).

DOI: $10.24326 /$ jasbbx.2018.1.3

HOLLOWAY, J. W., J. WU (2019): Red meat science and production. Volume 2. Intrinsic meat character. Science Press, Singapore, p. 136.

HOLMAN, B. W. B., T. I. R. C.ALVARENGA, D. L. HOPKINS (2020): The effect of fibre orientation, measurement interval and muscle on lamb meat drip loss values. Meat Sci. 161, 107959.

DOI: 10.1016/j.meatsci.2019.107959

JIMÉNEZ-COLMENERO, F., A. M. HERRERO, S. COFRADES, C. RUIZ-CAOILLAS (2016): Meat: eating quality and preservation. In: Encyclopaedia of food and health. (Caballero, B., P. M. Finglas, F. Toldrá, Eds), Academic Press, UK, p. 685.

KAIĆ, A., B. MIOČ, I. ŠIRIĆ, V. DRŽAIĆ (2016): Influence of sex and the slaughtering season on water-holding capacity and carcass composition in Istrian lambs. Vet. arhiv 86, 111-123.

KIM, H. W., Y. H. BRAD KIM (2017): Effects of aging and freezing/thawing sequence on quality attributes of bovine $\mathrm{Mm}$. gluteus medius and biceps femoris. Asian-Australas. J. Anim. Sci. 30, 254-261.

DOI: 10.5713 /ajas. 16.0279

KIM, H. W., E. S. LEE, Y. S. CHOI, J. H. CHOI, D. J. HAN, H. Y. KIM, D. H. SONG, S. G. CHOI, C. J. KIM (2011): Effects of aging period prior to freezing on meat quality of Hanwoo muscle (Longissimus dorsi). Korean J. Food Sci. Ani. Resour. 31, 799-806.

DOI: 10.5851/kosfa.2011.31.6.799

KOOHMARAIE, M. (1996): Biochemical factors regulating the toughening and tenderization process of meat. Meat Sci. 43, 193-201.

DOI: 10.1016/0309-1740(96)00065-4
RANT, W., A. RADZIK-RANT, M. ŚWIĄTEK, R. NIŻNIKOWSKI, Ż. SZYMAŃSKA, M. BEDNARCZYK, E. ORŁOWSKI, A. MORALES-VILLAVICENCIO, M. ŚLEZZAK (2019): The effect of aging and muscle type on the quality characteristics and lipid oxidation of lamb meat. Arch. Anim. Breed. 62, 383-391.

DOI: $10.5194 \% 2$ Faab-62-383-2019

RASMUSSEN, A. J., M. ANDERSSON (1996): New method for determination of drip loss in pork muscles. Proceedings of the $42^{\text {nd }}$ international congress of meat science and technology, 1-6 September, Lillehammer, Norway, pp. 286-287.

SANTOS, L. E. S, J. P. TEÓFILO, M. Q. FREITAS, E. A. CUNHA, M. M. H. HAGUIWARA (2012): Effect of pre and post-slaughter processes on meat characteristics of Santa Ines ewes discarded due to age. Food Sci. Technol. Int. 32, 455-463.

DOI: $10.1590 / \mathrm{S} 0101-20612012005000069$

SAS Inst. Inc. (2004): The SAS System for Windows. Version 9.4. Cary. NC. SAS Institute.

SCHULTE, M. D., L. G. JOHNSON, E. A. ZUBER, B. M. PATTERSON, A. C. OUTHOUSE, C. A. FEDLER, E. M. STEADHAM, D. A. KING, K. J. PRUSA, E. HUFFLONERGAN, S. M. LONERGAN (2019): Influence of postmortem aging and post-aging freezing on pork loin quality attributes. Meat and Muscle Biology 3, 313-323. DOI: $10.22175 / \mathrm{mmb} 2019.05 .0015$

WARNER, R. D. (2017): The eating quality of meat - IV Waterholding capacity and juiciness. In: Lawrie's meat science. $8^{\text {th }}$ ed. Woodhead Publishing, UK, p. 419.

YOUNG, O., B. HOGG, B. MORTIMER, J. WALLER (1993): Collagen in two muscles of sheep selected for weight as yearlings. New Zeal. J. Agr. Res. 36,143-150.

DOI: $10.1080 / 00288233.1993 .10427495$

Received: 4 March 2020

Accepted: 5 June 2020

KAIĆ, A., I. ŠIRIĆ, S. ŽGUR, G. ŠUBARA, B. MIOČ: Utjecaj dobi pri klanju i zrenja na sposobnost zadržavanja vode i mekoću ovčjeg mesa. Vet. arhiv 90, 611-616, 2020.

\section{SAŽETAK}

Cilj istraživanja bio je utvrditi sposobnost zadržavanja vode (gubitak mesnog soka - DL, kalo odmrzavanja - TL, kalo kuhanja - CL) i mekoću (Warner-Bratzler sila presijecanja, WBSF) mesa istarske ovce obzirom na dob pri klanju i dužinu zrenja (1, 7, 14 dana). U svrhu istraživanja sveukupno je bilo korišteno 30 uzoraka ovčjeg mesa (m. longissimus thoracis et lumborum; LL). DL je izmjeren prema EZ metodi 24 i $48 \mathrm{~h}$ post mortem, dok su TL, CL i WBSF utvrđeni na uzorcima mesa držanih na zrenju tijekom 1, 7 i 14 dana. Ovčje meso držano na zrenju jedan dan imalo je znakovito niži TL (P <0,05; 7,76\%) od mesa držanog na zrenju sedam dana (9,91\%) i 14 dana (9,32\%). Ovčje meso držano na zrenju jedan dan imalo je znakovito veću tvrdoću mesa $(\mathrm{P}<0,05 ; 43,89 \mathrm{~N})$ od mesa držanog na zrenju sedam $(33,92 \mathrm{~N})$ i $14(28,23 \mathrm{~N})$ dana. Neznatne razlike između istraživanih pokazatelja ovčjeg mesa držanih na zrenju sedam i 14 dana ukazuju da ne postoji opravdana svrha zrenja dužeg od sedam dana. Očekuje se da će dobiveni rezultati pridonijeti daljnjim istraživanjima povezanih sa kraćim zrenjem, senzorskom analizom i prihvatljivosti ovčjeg mesa od strane potrošača.

Ključne riječi: ovca; sila presijecanja; gubitak mesnog soka; kalo odmrzavanja; kalo kuhanja 